\author{
YAROSLAV PASKO, \\ Borys Grinchenko Kyiv University (Kyiv, Ukraine) \\ e-mail: paskocivil@yahoo.com,ORCID 0000-0002-2806-7341
}

HENNADII KORZHOV,

Igor Sikorsky Kyiv Polytechnic Institute (Kyiv, Ukraine)

e-mail: korzhovgena@yahoo.com, ORCID 0000-0001-5459-0702

\title{
'SOLIDARITY' AS A COMMUNITY OF CIVIL SOCIETY
}

The proposed research analyzes the external and internal factors that determine the specificity of Solidarity as a community of civil society and driving force of social and cultural changes in Poland. The external factors of these processes are connected with the critical interpretation of social cynicism and 'Marxist collectivism' by autonomic group in Polish society. These processes of social corrosion are considered as a social alienation and consequences of social fragmentation in Soviet period. The paper focuses on the danger of collision between national and colonial versions of memory as well as the social challenge of guarantee the possibility of an integral development of man and community. The internal factors actualizes the interpretation of Solidarity as a community of social changes, the positive activities of Catholic church, religious and secular leaders, of their theoretical ideas in the context of evolution of Solidarity from traditional community to modern one based on democratic values, social and economic motivations. The analysis is centered on the theoretical problem of civil trust, and the meaning of cultural, religious, and moral factors in the activities of Solidarity movement. We regard the problematic of Solidarity at the same time from republican and liberal positions. Synthesizing the different approaches to the historical memory, and to the experience of formation and evolution of community, the paper also explores the role and significance of Solidarity in the process of post-soviet values transformation. The article deals with the value prerequisites of moral-normative community in the country of the former socialist camp, the revival of national identity, as well as the elimination of historical contradictions provoked by the communist regime. The study confirms that social changes became possible due to the successful combination of communitarian and liberal foundations of civil society, the elimination of external influences, and achieving autonomy from the Russian and Soviet historical heritage. In the period of Soviet occupation in Poland, throughout two decades a fundamentally important intellectual discourse was formed, which, in spite of the unfavorable political context, became a consolidating and integrating socio-political force that successfully resisted the totalitarian and unifying tendencies of communist regime. Intellectuals, along with the Catholic church, have become a driving force for social change, playing a key role in shaping the social strategy of national development that has changed the social landscape of 'communist' Poland.

Key words: civil society; values; community; solidarity; moral-normative foundations; communitarian and liberal principles; historical memory; intellectuals; discourse.

\section{Introduction}

Conducting study of the theoretical and socio-historical background of social transformation in post-communist countries is one of the priorities for contemporary social theory. Poland provides an example of remarkably successful modernization of society in the aftermath of the collapse of communism in Central and Eastern Europe which makes its experience of transformation particularly appealing for scholars. An important role in the social changes of the 1980-s was played by Polish Solidarity movement, which, by uniting different social groups, became a leading transformative force in Polish society. In its activities, it relied on a combination of traditional and modern values that played a leading role in the process of forming a resistance movement to the Soviet and Russian 'communist projects' in Central and Eastern Europe.

One of the prominent leaders of Solidarity in the 1970s and 1980-s, a symbol of spiritual resistance to the tota- litarian regime Adam Michnik, while illustrating the specifics of the socio-cultural transition, updates the discourse of civil society in Poland. According to the longtime editorin-chief of Gazeta Wyborcza, political ideas declared by Solidarity promoted a democratic social alternative in the state and became a manifestation of social disobedience against authoritarian rule. Considering the situation in Poland at the turn of the 1980-s and 1990-s, the Polish dissident notes that Solidarity became 'the embodiment of spiritual and secular unity on the basis of anti-totalitarian frame' (Michnik, 1998). The 'social agenda' proposed by the national resistance movement fits in perfectly with the European theory of social transformation, which is directly related to the awareness of the moral, regulatory, sociocultural preconditions for the emergence of civil society in communist Poland.

The purpose of the presented article is to investigate the socio-cultural prerequisites for the emergence of 
Solidarity as a moral-normative and functional community of civil society, a factor in the consolidation of communist Poland, and a major driving force of social change that took place in 1989-1991.

One can identify the basic factors that contributed to the transformation of Solidarity from an independent trade union into a value-based civic community:

1) Catholic Church as a normative factor in supporting civic and socio-cultural initiatives of Solidarity has played an exceptional role in shaping the outlook of civil society in Poland. Sharing with dissidents the need to build a 'New Poland' on the traditional values of civil society, the church became a 'protective umbrella' for Polish intellectual community, ... cultivating civic culture, and activating the sphere of culture, education and self-help' (Wandych, 2006). The Church in Polish society of the 1970-s and 1980-s not only resisted the occupational tendencies of the society's disintegration but also promoted the reproduction of anti-communist intellectual discourse, performed an 'organic' moral-normative function, spreading values, clearly distinguishing the national value community from the mechanical association of people who function within a totalitarian frame.

2) There were powerful social movements that supported Solidarity, namely: the Gdańsk Liberal Movement, the Orange Alternative, the Kraków Intellectual Circle, and other socio-cultural platforms. Subsequently they became integral parts of Solidarity, called for communitarian unity and warned about the danger of the spread of violence and social servility with regard to totalitarian power. In fact, Solidarity succeeded to unite almost all socially active groups of Polish society and worked out the basic moral and normative criteria of opposition to power during the domination of communist regime. Barbara Szacka emphasizes that it was the 'normative dimensions of Polish community that prevented it from accepting the Soviet version of historical memory, the heroes of which were imposed to Polish society' (Shatska, 2011). It is useful to note the productivity of communitarian and republican principles for Polish society, since they became a precondition for essentially different, compared to communist period, value shifts. In this context, it is worth recalling the words of the leader of the resistance movement of the time and the former President of Poland Lech Wałęsa, who justifying the need for social change states that 'we historically existed ... in a free republic where ... independently built our social order' (Giżewska, 2010). According to Wałesa, not only the democratic demands to destroy the monopoly of the system of state socialism but also reciprocity and solidarity in the community are of particular importance for its historical memory. Communitarian principles made it possible to crystallize civil society as a valuable opponent of communist rule.

3) The liberal foundations used in the activities of the independent trade union played a key role in the delegitimization of communist system. What linked Solidarity with liberalism is the central issue of individual freedom, the preservation of its complex rights, including social ones, which are an integral component of social liberalism. Compliance with social rights was made possible due to the striving of the independent trade union for the synthesis of republican and liberal foundations, as well as the combination of instrumental and axiological dimensions of rationality.

4) Importantly, it is impossible to imagine the revolutionary role of Solidarity in the events of 1989-1991 without the spreading out of public sphere in the 1970s and 1980s, without the wider society's appreciation of the value role of secular and religious intellectuals, which became the driving force of social and historical changes in Polish society.

\section{Methodological foundations of the study}

Understanding the phenomenon of the Polish independent trade union Solidarity not only as an institution of collective self-expression "on the basis of autonomous principles of self-determination in relation to a metropolis" but also as an institution of civil society is a fundamental constituent of social transformation research. Civil society in Poland has transformed an atomized society into a valuebased community which has consistently displaced socialist stereotypes.

An important methodological underpinning of our study is the theoretical and practical legacy of John Paul II, who enormously contributed to the 'destruction of the communist state control over public discourse, including the discourse of historical memory' (Jan-Pawet II, 1996). It is worthwhile to emphasize the input to the spread of civil society discourse done by a well-known Polish intellectual Adam Michnik who views dissident initiatives and the institution of church as 'important safeguards against the domination of communist system and a virtuous alternative to it' (Michnik, 1983). The intellectual achievements of such dissimilar intellectuals undoubtedly helped initiate the emergence of a new public space and communication communities which proved to be important opponents of totalitarian power and defenders of public interest. They promoted the development of rational criticism of the Communist government's policy within the framework of open public discourse and the introduction of the qualitatively new form of self-organization in Polish society.

One of the leading Polish intellectuals Jacek Kuroń points out that the civic 'strategy was to constantly expand the sphere of self-organization of society, civil liberties and human rights by creating a constant pressure on power from civil society' (Kuroń, 1984 a). The thinker envisioned a consistent transformation of Polish society through gradual changes in the communities themselves. The primary methodological guidelines in comprehension of Solidarity as a normative community are presented in the works of Andrew Arato (1981-1982), Professor of The New School for Social Research in New York, and Zdzisław Pełczyński (2007), who in their theoretical approaches hinge upon intellectual tradition of Antonio Gramsci.

The term civil society used by Andrew Arato is closely linked to the theoretical concept of the famous Italian socialist theoretician. The American scientist reformulated theoretical positions of the political prisoner of the fascist regime of Mussolini in accordance with the experience of the countries from Soviet domination orbit. At the same time, the researcher criticizes Hegel's vision noting that none of the criteria of the German scientist were implemented in the countries of Central and Eastern Europe. The 'system of needs' of the German philosopher was replaced by central planning, the institutions of pluralism by a single party monopoly, and the rule of law - by the notion of justice violated by the privileges of the nomenclature ruling class. Arato points out that a 'degraded Hegelian project' has been implemented in socialist countries (Arato, 1981).

The American researcher is convinced that the activities of opposition in Poland fit into the context of civil society and have every reason to become an ethical community oriented to the discourse of 'common good'. Arato puts 
emphasis on the need for a 'socialist civil society' (Arato, 1981-1982). The scientist considers this idea extremely attractive for gradual changes in the countries of Soviet socialism but at the same time voices reasonable doubts about its practical realization in the conditions of the communist dictatorship.

Borrowing the theoretical framework from the above American scholar, Zdzisław Pełczyński examines the 'problems of civil society in the context of the struggle of different social groups for domination' (Pełczyński, 1998). No doubt, the discourse of Antonio Gramsci became very relevant for the former communist countries in the 1970's and 1980's. According to Pełczyński, in conditions of Poland's social development the role of the bourgeoisie in the economic sphere is played by intellectuals who are not only opponents of communist power but also the driving force of the processes of social revival. In a spirit of Gramscian discourse, civil society is seen as a system of non-governmental organizations and institutions serving the interests of community. The attractiveness of Gramsci's ideas for dissident intellectual discourse was in their appeal to strengthen the rights of communities and groups, the special mission of intellectuals who create an autonomous space of freedom - preserve social and individual autonomy from the communist state.

A distinct methodological position is the liberal one presented by Andrzej Walicki and Ireneusz Krzemiński. They argue that civil society is primarily based on the maxim that every person, beyond his or her importance to society, has the right to decide his or her own destiny and has a voice in all public affairs. According to Krzemiński, the social processes that are intensifying in Poland owing to nongovernmental organizations open up the 'ideals of democracy' to the country (Krzemiński, 1996). Democracy is regarded as fundamental to the existence of man and defines the conditions for the functioning of social bonds between people. At the same time, the Polish scientist criticizes Solidarity and considers it, from the right ideological positions, as a contradictory community of civil society and the embodiment of socialist mentality. Walicki states that this community is characterized by "belief in the omnipotence of political will and the magical power of government that holds us back, produces and can do anything" (Walicki, 1984). Within this ideological approach, Solidarity is seen simultaneously as a democratic and totalitarian community.

Ireneusz Krzemiński ties civil society with democracy, positive freedoms, and assertion of dignity. The researcher stands for the possibility of combining liberal qualities of citizens with the existence of Catholicism. He claims that 'the moral authority of Church does not contradict the existence of civil society and liberal democracy' (Krzemiński, 1984). He believes that since the last days of August 1980, the idea of civil society and civil liberties, which could have been deduced from Christian tradition and social doctrine of Catholic Church, has been implemented into the public life of Poles. A Christian liberal Mirosław Dzielski, who is the most famous representative of the modernization studies of Polish society, takes a similar position (Dzielski, 1995a).

The opposite methodological vision of civil society is the republican-communitarian one. It hinges upon the moral substance of democracy and is developed within the framework of Aristotelian approach assumed by Polish society. Bronisław Świderski (2004) and Dariusz Gavin (2008), within their theoretical line, quite logically consider Solidarity as a republican community. Analyzing the image of solidarity in the eyes of its members, Grzegorz Bakuniak states that in the 1980-s man and community became the central categories for new labor movement. "The community myth within such a vision must be interpreted in the context of social development, where each member of the community is necessary for the proper functioning of the whole. According to the opinion of sociologists, since the beginning of the August strikes, union members have been dependent in their behavior from the realization of common interests" (Bakuniak, 2005). Within this model, it is quite obvious to interpret solidarity as a community of civil society.

\section{Results and Discussion}

Church as a Value Factor of Solidarity Formation

In the 1970-80-s Catholic church became a foremost political actor in Polish society, correcting the worldview and ethos of the leaders of anti-totalitarian movement. According to Jerzy Szacki, - and this is confirmed in the speeches of the leaders of dissident movement of the time, - 'the church played a leading role in the public life of communist society' (Szacki, 1994). The reasons for this are obvious given that for two centuries it was a large national institution that had considerable autonomy, exercised various control functions in an institutionally weak society, and played, in a sense, the role of civil society. However, it is quite obvious, - and here we are in full agreement with John Hughes, - that Catholicism could not promote the advance of liberal ideas, since it "was an active opponent of liberalism as a philosophy of the false and immoral, materialistic and anti-social" (Hughes, 1944). At the institutional level, the principles of both communist and liberal ideology were equally unacceptable to the church. The former Pope John Paul Il's words found in the encyclical Solicitudo rei socialis can serve as a confirmation of this thought. The encyclical states that 'the social teaching of the church is critical of both capitalism and Marxist collectivism, since neither guarantees the possibility of the integral development of man and community. Herein lies the cult of money, technology, and class. Each of the blocs contains an inclination towards imperialism and neo-colonialism' (Sollicitudo rei socialis, 1997: 447). The hostility of socialist ideas to Catholicism is underlined by Leo XIII who claims that there are "anthropological errors of real socialism which subjugates the individual to economic and social mechanisms, ignores the individual as a subject of moral decision-making, degrades private property" (Gorski, 2006). Socialist ideas related to atheism and the theory of class struggle were unacceptable to the church.

By opposing to liberal and socialist visions of social development, the church approved for Poland the type of society that existed at the end of World War I when powerful civil society structures that hindered the transformation of labor into commodity were created. The welfare state controlled the free market and social justice. In the encyclical Centesimus annus, John Paul II recognizes the civilizational importance of democratic liberalism, the positive role of the market, modern economy and entrepreneurship, which legitimize for Solidarity the important role of the individual as a decisive productive factor in society's development. However, the Pope puts emphasis on the danger of directing society to the absolute maximization of the profit as an indicator of social development, weakening the role of social well-being and safety, neglect of 'human and moral factors that have a priority in modern society' (Centesimus annus, 1997: 655). In striving for a 
'reconciliation of the world of labor and the world of capital' J.Kuczyński sees an attempt at a synthesis of the free market (Kuczyński, 1998).

John Paul II at the meeting with Solidarity leaders in 1987 questioned their efforts to 'turn Solidarity into an ideological European community, which being guided by propaganda slogans would become part of ultra-liberal and consumerist system' devoid of authenticity (Zięba, 1991).

The public support by representatives of the 'independent trade union' of the social doctrine of Church, in general, and the position of the Pope, in particular, by representatives of the 'independent trade union' shows that under the critical conditions of preserving Polish sovereignty Solidarity focused on the implementation of the idea of Christian and national unity. Solidarity did not avoid resolving the basic contradictions that confronted civil society at the time. One of them is the problem of coexistence of the national community with the socially and culturally unacceptable occupational social institutions, first of all, the communist state.

In the context of authoritarian politics, the democratic opposition articulates a program to safeguard all publicindependent initiatives and to enhance the activities of institutionalized forms of civil society. Grass-root initiatives are seen by democratic community as alternative forms of public life. In Jacek Kuroń's and other Solidarity theorists' opinion, 'society must keep distance from power and the representatives of dissident movement must not seek to occupy any state posts' (Kuroń, 1984 b). Instead, this intellectual discourse proposes a qualitatively new form of social self-government and representation which presupposes the liberation of society from any dependence on the state.

Such liberation implies a comprehensive political and economic program, which should be borne by workers, representatives of self-governing organizations, and entrepreneurs who form a civil society independent of the state. In his 1977 Notes on Self-Government Jacek Kuroń, emphasizing the importance of autonomous civic community, states that 'every social self-government initiative violates the monopoly of the state and, thus, the foundations of the existence of communist power' (Kuroń, 1977: 58). In his view, the program of self-organization of Polish society into independent social movements and institutions should become the only way to realize the goals of opposition and aspirations of society.

In the early 1980-s Adam Michnik, compliant with the vision of Joseph Glemp, emphasized the importance for Poland of the 'Third Way which presupposes the loss of the monopoly position of official state' (Michnik, 1984a: 87). The latter should give way to self-governing structures and free communities, first of all, Solidarity. It has played a decisive, exceptional role in the Polish society and undergone several stages of its development since the start of the August strikes in Gdańsk and Szczecin.

Stage 1 (August - December 1980). The Independent Mining Union distanced itself from official politics and concentrated on creating social bonds and democratic society.

Stage 2 (December 1980 - August 1981). Realizing that the primary social model has exhausted itself, Solidarity with the help of the church sought for political opportunities to rebuild the state. The first attempts at achieving compromise with the authorities pointed to the neo-corporative nature of relations between the state and society. Within this model, the communist state focused on the crushing of all independent initiatives, both public and private.

Stage 3 (August - December 1981). Solidarity is increasingly becoming political in nature and, at the same time, focusing on the development of civil society as a pillar for new community initiatives.

Stage 4. From the end of martial law to the overthrow of communist regime, Solidarity centered on the formation of a qualitatively new society based on democratic cultural values and civilizational principles.

Despite the revolutionary nature of its program, Solidarity leaders were aware, - and here the influence of the Church is undeniable, - that the Hungarian and Czech revolutions of 1956 and 1968 were defeated due to the efforts of civil society to change the communist system by means of one revolutionary step. According to A. Arato, Solidarity by making concessions to the ruling party laid the foundations for a balance between the communist state and democratic society, creating a situation where 'society is no longer an institution of service to the state, but acts as its opponent and critic' (Arato, 1984: 13).

In the process of building a new social order, Solidarity as a nation-wide community responded to the social contradictions in Polish society: between collectivism and individualism, the individualistic and communitarian visions of the development of future society.

\section{Solidarity as a Republican Community}

It is very important for better understanding of Solidarity to consider two antinomic approaches: liberal and republican-communitarian. The fundamentally different epistemological prerequisites for the two approaches are drawn by Andrew Arato and Jean Cohen (Arato, Cohen, 1984). Within the first position, individual rights are fundamentally universal in nature and are ingrained in the very nature of the individual and in the subjectivity of the human personality. Adam Seligman notes the differences between Western and Central European, in particular Polish, versions of civil society: the latter is not inherently liberal (Seligman, 1992: 202-203).

Communitarianists criticize this concept arguing that human rights are derived from the collective foundations of the existence of community, since the individual does not have the autonomous basis for moral judgment but acquires it in the process of interaction within the community to which it belongs. As a consequence, it is common good which is of utmost importance for the development of community not the individual and his/her rights. Individuals acquire rights only to the extent that rights derive from the concept of common good.

In this context, Magdalena Gadomska draws attention to the fact that liberal ethos for Solidarity as a social movement is unacceptable. It is so over-saturated with individualism that does not imply the creation of true community. "Liberalism treats tradition and morality as somewhat irrational depriving modern political structures of any ethical basis. Instead, it creates an atomized society of asocial people" (Gadomska, 1984: 25).

Krzemiński holds the same opinion arguing that the idea of civil society is connected with the idea of community and can be deduced from the Christian tradition. "There is an organic connection of Solidarity with both individual and societal freedom" (Wnuk-Lipiński, 2012). The Polish researcher accentuates that the role of the church for Poles was to involve spiritual and cultural principles because "Church was perceived not only as an institution that guaranteed and defended human dignity, natural human 
rights, but also a factor in forming community on the basis of communitarian values" (Krzemiński, 1987). It can be stated that in Polish conditions of the dominance of traditional culture and public values enrooted in culture European liberalism could not become the basic platform for the development of Solidarity.

Analyzing the social ideas that influenced the formation of Solidarity, it should be stressed that liberal ideas accepted by Polish community only when they relied on public obligations, emphasized the priority of public foundations over private ones and conflicted with the individualistic liberal version. In this context, Solidarity cannot be regarded as an ethical community fully consistent with Western liberal tradition.

Instead, the dominance of communitarian tendencies in the existence of Solidarity is particularly noticeable in the context of respect for the dignity of human labor. The anti-liberal and anti-communist concept of the philosophy of labor implied that it was based on commitment and mutual assistance in the community. In this context, the normative ideal for Polish community is owner who inherits the tradition of generations and takes care of his own economy, and whose work and economy is related to the care of the land.

The ideological leaders of Solidarity repeatedly emphasized the significance of traditional values, which are the basic constant of communitarianism. Joseph Tischner stresses that Solidarity Movement 'cannot be understood without attachment to religious factor' (Tischner, 1992: 27). Smolen points out that religious symbols "played a big role, both during the 'August strikes' and afterward, in the period of martial law" (Smolen, 2000: 99). Reproducing the sense of citizenship, and the concept of national sovereignty had strong religious connotations in Poland.

It is easy to see the evolution of the views of Lieszek Kołakowski (Seligman, 1992: 201) and Adam Michnik, as well as other liberal leaders of the Polish national movement in relation to religion and Church. "We thought, A. Michnik acknowledged, that, for whatever reason, the main enemy of development was, where it has always been, traditionally right ... because their structure is hierarchical, following the example of the Roman Catholic Church". For liberals, human emancipation was seen as liberation from religion, because "we were accustomed to believing that belief in God automatically leads to impoverishment of the individual, it is a limitation of human autonomy and individual's humiliation" (Michnik, 1984b).

However, the influence of church on community and the liberal wing of Solidarity were so powerful that they caused a rethinking of liberal views. A convinced liberal $A$. Michnik, during the dramatic events of the martial law, argued that the life of a Pole cannot be understood without the meaning of the life of Christ. He emphasized that without Christ we would not be able to understand the spiritual level of this people - without Christ, who is a symbol of patience and the Good News" (Michnik, 2017: 35). In this context, it was the Solidarity-initiated return of the rights of religion that was perceived as an opportunity for citizens to make free choices, including the exercise of religious cult, which within the community was viewed not only as a matter of individual conscience but as a public affair.

\section{Memory as a component of national community}

Solidarity as a community was asserted in some opposition to liberal tradition that does not require historical memory and is seen as a rejection of various cultural strata.
It is widely accepted that liberal democracy is incompatible with honoring the past. The distancing of the liberal tradition from memory is also noticed by Martin Król, who in the book Liberalism of Fear or Liberalism of Courage argues that "[liberal] doctrine and liberal practices are fundamentally opposite to memory" ... liberals have always been fugitives ... from memory (Król, 1996: 152). Bernard Barber is of the same opinion - he emphasizes that "liberals have trouble recognizing that our actions are the result of the actions of previous generations. If the past, historical heritage, is recognized as constitutive of... the community, it is difficult to consider it as the result of a free contract, a contract between mature independent entities. On the other hand, if individuals are completely autonomous, then it is impossible to speak of shared consciousness or collective memory" (Barber, 1988: 48).

An opposite position is presented by Wojciech Roszkowski, who notes that democracy for "Solidarity has always been linked to tradition that is nothing but a time-honored democracy". The tradition for him is the 'democracy of the dead. There is no democracy that does not rely on shared memory and symbols, although it is clear that Polish society has never been completely unanimous in these matters' ${ }^{1}$.

It is difficult to imagine a traditional civil society community and political movement Solidarity without an important socio-cultural precondition: the republicancommunitarian vision of historical memory. The specificity of Polish collective memory in the 1970 s and 1980 s was associated with the struggle of Polish civil society with the dominant Soviet historical patterns that objectively weakened national sovereignty. It is quite clear that during the communist period Polish nation remained split between two historical experiences: the Soviet occupation of the eastern part of Poland and the German and Austrian domination in the western part. The creation of shared collective memory was complicated by official Soviet propaganda, which for a long time consistently delineated the historical landmarks of totalitarian power. The occupational authorities demanded not only "the displacement of any historical data from Polish public consciousness that would impair the image of a social justice country and the great friend of the Soviet Union, eclipsed the sense of gratitude for Poland's liberation from German occupation, but also any mentions of before-war Poland" (Szacka, 2011: 154-155). For the communist authorities, who viewed the historical past as the last fortress of their own political influence, it was clear that the reproduction of national memory objectively led to the de-legitimization of the Soviet social order.

The Soviet version of historical memory meant ignoring Polish national identity, multiple crimes, and deportation of people from eastern Poland to the Soviet Union camps in Starobilsk and Ostashkiv. At the same time, the merits of the Polish soldiers who fought in the Polish Armia Krajowa were silenced, whilst the soldiers of the Polish Armia Ludowa were glorified. Political persecution committed by Soviet authorities has been concealed throughout the entire period of the Polish People's Republic. However, since the mid-1970-s Solidarity, representing the demands of civil society, has shifted the focus of society's attention from the class aspects of Polish history to the problem of restoring common identity for all the Poles. Thanks to Solidarity, there was a rapid growth of uncensored historical editions that published information about the Poles'

1 Cyt. za : Roszkowski, W. (2000). Zawieszeni w skoku. Rzeczpospolita. styczeń. 
suffering inflicted by the Soviet authorities. The central historical symbol of Polish resistance movement - Katyń helped to overcome the social divide provoked by Soviet occupation. Under the pressure of Solidarity, the Communist leadership in 1988 agreed that one-dimensional interpretation of Polish historical memory as the struggle of the Polish People's Army on the Eastern Front hinders the formation of unified national historical vision. According to Barbara Szacka, the formation of the latter is possible as a result of powerful intellectual reflection: through the true reproduction of the 'tragic historical events of modern Polish history (the Warsaw Uprising, the deportation of the Poles to the hinterland of the USSR during World War II and afterwards, the attack of the Soviet Union against Poland in 1939, the death of General Sikorsky) (Ibid: 158). It should be noted that under the influence of Solidarity there was a crystallization of the collective memory of the Poles, which is fully reflected in the policy of today's ruling party Law and Justice (Prawo $i$ Sprawiedliwość). At the heart of the contemporary position of the Polish community is the appeal to historical justice and constant rethinking of the occupational experience at a new historical level. This tendency became obvious after the tragic 'Smolensk tragedy' of 2010 comprehension of which is still ongoing.

\section{Liberal Foundations of Community: Mirosł aw Dzielski}

There is a generally accepted theoretical position that attests to the weakness of liberal principles in Polish society, lack of their historical rootedness in the memory of Polish national community. In particular, the weakness of liberal ideas is pointed out by the leading Polish social theorists of the XX century Jerzy Szacki and Leszek Kołakowski (Kołakowski, 1984). The focus is on the incompatibility of liberalism with the important dimensions of historical memory and the mentality of Polish society. To some extent, this position is consistent with historical reality. Jerzy Jedlicki, who in the 1980-s defended the idea of shared responsibility for the future, emphasizes that 'within the limits of liberalism everything historical will soon be irrelevant, giving way to pragmatic liberal social norms' (Jedlicki, 1997: 15).

However, the importance of liberal ideas for society should not be underestimated. This is especially true for Solidarity, which, having been criticized by the Polish community from right ideological positions during the 1980 -s, changed in response to the social challenges of the times, which necessitated the modernization of Polish society.

One of the most consistent intellectual critics of Solidarity, Andrzej Walicki notes that the negative attitude to liberal ideas in Polish society has its reliance point in Adam Mickiewicz's historical heritage. An outstanding symbol of Polish culture "idealized ancient Polish republicanism and old Polish freedom", emphasizing the danger of losing the spiritual unity of national community (Walicki, 2006: 44).

According to Mickiewicz, the decline of Poland and its loss of independence were provoked not by the weakness of liberal freedoms, European norms and rules but by the lack of a "charismatic leader, a lack of trust in the community, and strong social ties" (Ibid: 44-45). In particular, the Polish poet claims that in Polish history there was always lack of people capable of carrying passion and strength. In his view, unanimity in the Diet (Sejm), not Western freedoms, is a precondition for the emergence of an ideal community.

Considering the poet's messianism as anti-rational, Walicki states that for Solidarity Mickiewicz's words were a signpost that an individual mind cannot be a compass in the transformation of social relations. A new society cannot be created mechanically in accordance with rational plan. Quite the opposite, it must 'sprout from tradition and customs and create an organic li ving integrity' (Ibid: 30). Even a tougher version of romantic messianism, according to Walicki, is represented by Juliusz Słowacki, who is a republican elitist. While focusing on the need to' return to the noble traditions of Liberum Veto, he cannot be a perfect example for modern community' (Ibid: 31$)$.

Bronisław Świderski draws attention to the danger of the implementation of romantic concepts in the actions of Solidarity. He emphasizes that the romantic use by the leaders of the independent trade union of the concepts of homeland and family not only 'contradicts the traditions of ancient democracy, but also provides the ground for the emergence of the totalitarian state' (Świderski, 1996: 101).

Liberal criticism of the above republican-romantic ideas and their materialization in public life has transformed Solidarity from republican into conservative-liberal community. Evidence of this is supplied by Ewa Morawska in her Civic Religion against State Power in Poland where importance of romanticist ideas in the process of eliminating the totalitarian social order is strongly emphasized. The researcher highlights the importance of the political, civil and social rights of the individual in the process of restoration of democratic society, the defining role of civic religion, which appeals not only to historical memory of free Poland, but also to the 'liberal tradition of respect for individual rights' (Morawska, 1984: 29). She notes that an important prerequisite for liberal ideas in Poland can be found out in personal Christian dimensions, Christian liberalism, which becomes the core of the program of social modernization of Polish society.

Constructing a model for the development of civil society in Poland, one of the founders of Christian liberalism in Poland, Mirosław Dzielski emphasizes that the enemy of Polish society is not the police, but only customs that rely on romantic and socialist social consciousness. The researcher articulates that Solidarity should emerge as a 'modern capitalist community based on individualistic initiatives of people' and contribute to the civilizational development of Polish society, to modernization that is integral to changes in moral and economic spheres (Dzielski, 1995b: 70).

It is about launching a comprehensive model of liberal society development based on a strategy of small steps and achieving historical compromise in Polish society. An important role in the formation of liberal worldview in the development of social change is played by moral normative principles. In this context, we cannot agree with the opinion of David Ost who argues that the paradox of Eastern Europe was that collectivist revolutions introduced in this region led to the construction of individualistic system. According to one of the best analysts of Polish community, the market economy was introduced "thanks to those oppositionists who have long been responsible for the values of community" (Ost, 2007: 103).

In our opinion, there is no paradox here because thanks to such leaders of Solidarity as Dzielski and Kołakowski a special Polish vision of liberalism was formed. It assumes the primacy of morality not only in political but also in economic life. It is about building a new Polish community which is to be based on the moral, religious and generally spiritual prerequisites for the development of capitalism.

The words of Dzielski, who considers the Church institution as a prerequisite for the development of liberal 
foundations in society, appear to be very relevant in this context. Describing the importance of the church in Polish society "as a teacher of political culture, ... an institution that distinguished itself from radical democracy on value level and adopted the principles of the liberal concept of political culture", the scientist emphasizes the Christian principles of liberalism (Dzielski, 1995a: 294-295).

It is about forming a liberal-conservative community, which, while maintaining the capitalist agenda of social development, remains to be based on Christian values. In his spiritual testament written in 1989 Polish researcher claimed that the main task for Solidarity was to 'fight against totalitarianism and associated with it emptiness, and to endorse the ethical and Christian norms of European society' ${ }^{2}$

\section{Concluding remarks}

The process of the crystallization of Solidarity as a community of civil society was an outcome of long-term social evolution. It presupposed the formation of powerful intellectual discourse that mirrored not only the broad public discussion of the problems of interaction between the state, society and the individual, principles of individual and collective development, but also a deep immersion in the historical past, sacral and secular cultural contexts of the coexistence of diverse social communities and groups. We conclude that the fundamental principles of civil society were exemplified in the ethos and collective practices of Solidarity at several levels: 1 ) a value distance from the Soviet and Russian historical heritage, based on a critical understanding of imperial statism as hostile to national Life-world, as alien in cultural and civilizational terms; 2 ) the reproduction of a powerful traditionalcommunitarian component, which included strong moralnormative and religious foundations, unifying national identity, and value-based unity of the community, as well as laid the foundation for the further development of social freedom in its republican version; 3 ) the gradual rationalization of community and involvement of strong social and liberal-economic motivations in its programmatic activity; 4) the cooperation and coordination of different social groups, in which Church and intellectual community played a decisive role in generating Solidarity's strategy and tactical objectives. They greatly contributed to not only the delegitimization of communist system but also the elaboration of principles to create a new society.

\section{REFERENCES}

Arato, A. (1981). Civil Society Against the State: Poland 198081. Telos. March, 20: 171-211.

Arato, A. (1981-1982). Empire vs. Civil Society: Poland 19811982. Telos. (New York), No. 50.

Arato, A. (1984). The Democratic theory of the Polish Opposition: Normative Intentions and Strategic Ambiguities. Working papers, 15

Arato, Andrew, and Cohen, Jean (1984). Social Movements. Civil Society and the problem of Sovereignty. Praxis International. Vol. 3. No. 4.

Bakuniak, G. (2005). My Solidarność - nowy związek we własnych oczach. Polacy-jesień 80. (Warszawa): 105-118. (In Polish)

Barber, B. (1988). The Logic and Limits of Trust. Washington, p. 48.

${ }^{2}$ Cyt za: Walendziak, W. (1991). Miroslawem Dzielskim rozmawia. Widzieć mądrość w wolności. Ksiega pamieci Mirosł awa Dzielskiego, Praca zbiorowa pod redakcją B. Chraboty, KTP. S. 11-12.
Centesimus annus (1997). Encykliki Ojca Świętego Jana Pawła II. Kraków: Znak: 655. (In Latin)

Dzielski, M. (1995a). Duch nadchodzącego czasu. In: Odrodzenie ducha - budowa wolności. Pisma zebrane. Krarów: Znak. (In Polish)

Dzielski, M. (1995b). The spirit of the coming time. In: Rebirth of the spirit - the construction of freedom. Krarów: Znak. (In English)

Gadomska, M. (1984). Przemiany w percepcji procesów spolecznych. In: Spoleczeństwo polskie w czasach kryzysu. Warszawa, S. 25. (In Polish)

Gawin, D. (2008). Civil Society Discourse in Poland in the 1970-s and 1980-s. Discussion Paper. Berlin.

Giżewska, E. (2010). Filozofia publiczna Solidarności. Solidarność 1980-1981 z perspektywy republikańskiej tradycji politycznej. Narodowe Centrum Kultury. S. 131. (In Polish)

Gorski, E. (2006). John Paul Il's idea of Universalism. In: Dialog and Universalism. No. 11-12.

Hughes, J. (1944). The Church and the Liberal Society. Princeton University Press. Princeton. N.Y, p. 34.

Jan-Paweł II. (1996). Nauczanie społ eczne Kościoł a integegralną częścią Jego misji. Rome, S. 11-91. (In Polish)

Jedlicki, J. (1997). O pamęci zbiorowej. Gazeta Wyborcza. Z. 26-27 Lipca. S. 15. (In Polish)

Kołakowski, L. (1984). Gdy Diabeł może być zbawiony $i$ 27 innych kazań. Anneks, Londyn. (In Polish)

Król, M. (1996). Liberalizm strachu czy liberalizm odwagi. Warszawa-Kraków: Znak. (In Polish)

Krzemiński, I. (1984). Proces tworzenia niezależnych organizacji związkowych. Polacy-jesień'80 (Warszawa). (In Polish) Krzemiński, I. (1987). Religia i "Solidarność". Aneks. No. 48. (In Polish)

Krzemiński, I. (1996). Solidarność - sens ludzkiego doświadczenia. Mit i rozczarowanie. In: Solidarność. Projekt polskiej demokracji. Warszawa: Oficyna Naukowa, p.250. (In Polish)

Kuczyński, J. (1998). Wstep do universalizmu. Vol. 1: Ogrodnicy świata. Warszawa, S. 214. (In Polish)

Kuroń, J. (1977). Notatki o samorządzie. In: Polityka $i$ odpowiedzialność, Aneks. Nr. 13-14. S. 58. (In Polish)

Kuroń, J. (1984a). Zasady ideowe. In: Zło, ktore czynię. s. 37-60. (In Polish)

Kuroń, J. (1984b). Myśli o programie działania. Polityka $i$ odpowiedzialność, Aneks. Nr. 13-14. (In Polish)

Michnik, A. (1983). Listy z więzienia; Ugoda, praca organiczna, myśl zaprzeczna. Nowa. Warszawa. (In Polish)

Michnik, A. (1984a). Nowy ewolucjonizm. In: Szanse polskiej demokracji. Artikuł y i eseje. Aneks. S.87. (In Polish)

Michnik, A. (1984b). Powstanie listopadowe - Polskie pytania. Krytyka. Nr. 17. S. 80-88. (In Polish)

Michnik, A. (1998). Dlaczego potrzebujemy Kościoła?. In: Kosciół, Lewica, dialog. Warszawa, S. 302. (In Polish)

Michnik, A. (2017). Kościół, Lewica, dialog. Wybrane Adama Michnika. Zbiór pism, eseje, rozprawy i szkice z lat 1977-1997. S. 35. (In Polish)

Morawska, E. (1984). Civil Religion vs. State Power in Poland Society. S. 29

Ost, D. (2007). Klęska "Solidarności". Gniew i politika w postcomunistycznej Europie. Warszawa, S. 103. (In Polish)

Pełczyński, Z. (1998). Wolność, państwo, społeczeństwo. In: Hegel a problemy wspót czesnej filozofii politycznej. Wrocław. (In Polish)

Pełczyński, Z. (2007). Solidarność a odrodzenie społeczeństwa obywatelskiego w latach 1976-1981. In: Polska droga od komunizmu: refleksje nad historią i polityką 1956-2006. Warszawa. (In Polish)

Seligman, A. (1992). The idea of Civil Society. New York: Free Press. pp. 202-203. 
Smolen, D. (2000). Tłum czy społecznośc zorganizowana? Strajkująncy w stoczny Gdańskiej w Sierpniu 1980, in: Solidarność w Ruchu 1980-1981. Warszawa. (In Polish)

Sollicitudo rei socialis (1997). Encykliki Ojca Świętego Jana Pawła II. Kraków: Znak. (In Polish)

Świderski, Bronisław (1996). Gdańsk i Ateny: o demokracji bezpośredniej. Warszawa, S. 101. (In Polish)

Świderski, Bronisław (2004). Liberalizm na niby. Przegląd Polityczny. Nr. 67/68. (In Polish)

Szacka, Barbara (2011). Mynule - pamyat - mit. Chernivtsi: Knyhy-XXI, S. 29. (In Ukrainian)

Szacki, J. (1994). Liberalizm po komunizmie. In: Demokracja. Filozofia i Praktyka. Warszawa: Znak, S. 70. (In Polish)

Tischner, J. (1992). Etyka Solidarnosci oraz Homo Sovieticus. Warszawa: Znak, S. 27. (In Polish)

Walicki, A. (2006). Mesjanizm Adama Mickiewicza w perspektywie porównawczej. Warszawa. (In Polish)

Walicki, A. (1984). Myśli o sytuacji politycznej i moralno-psychologicznej w Polsce. Aneks. Nr. 35. (In Polish)

Wandych, P. (2006). Cena wolności. Historia Europy Srodkowo-Wschodniej od sredniowiecza do wspólczesności. Kraków: Znak.

Wnuk-Lipiński, Edmund (2012). Sotsiologiya publichnoy zhizni (transl. from Polish). Moscow: Mysl. (In Russian)

Zięba, Marcin (1991). Papież, wolność i kapitalizm. Kraków: Znak, S. 94.

\section{LIST OF REFERENCES LINKS}

Arato A. Civil Society Against the State: Poland 1980-81. Telos, 1981. March 20. P. 23-47.

Arato A. Empire vs. Civil Society: Poland 1981-1982. Telos (New York), 1981-1982. No. 50

Arato A., Cohen J. Social Movements, Civil Society and the Problem of Sovereignty. Praxis International. Oxford, 1984. Vol. 3. No. 4.

Arato A. The Democratic Theory of the Polish Opposition: Normative Intentions and Strategic Ambiguities. Working papers. 1984. 15 April.

Bakuniak G. My 'Solidarność' - nowy związek we własnych oczach. Polacy-jesień 80. 2005. S. 105-118.

Barber B. The Logic and Limits of Trust. Washington, 1988.

Centesimus annus In: Encykliki Ojca Świętego. S. 655. URL: https://opoka.org.pl/biblioteka/W/WP/jan_pawel_ii/encykliki/ centesimus_1.html

Ciżewska E. Filozofia publiczna Solidarności. Solidarność 1980-1981 z perspektywy republikańskiej tradycji politycznej. Narodowe Centrum Kultury, 2010.

Dzielski M. Duch nadchodzącego czasu. Odrodzenie ducha - budowa wolności. Pisma zebrane. Krarów: Znak, 1995.

Dzielski M. The spirit of the coming time. Rebirth of the spirit the construction of freedom. Writings. Krarów: Znak, 1995. S. 249-269.

Gadomska M. Przemiany w percepcji procesów społecznych. Społ eczeństwo polskie w czasach kryzysu. Warszawa, 1984.

Gawin D. Civil Society Discourse in Poland in the 1970-s and 1980-s. Discussion Paper. Berlin, 2008.

Gorski E. John Paul II's idea of Universalism. Dialog and Universalism. 2006. No. 11-12.

Hughes J. The Church and the Liberal Society. Princeton: Princeton University Press. N.Y, 1944.

Jan-Paweł II. Nauczanie społeczne Kościoła integralna częścią Jego misji. Rome, 1996. S. 11-91. Lipca.

Jedlicki J. O pamęci zbiorowej. Wyborcza. 1997. Z. 26-27

Kołakowski L. Gdy Diabeł może być zbawiony i 27 innych kazań. Anneks (Londyn).
Król M. Liberalizm strachu czy liberalizm odwagi. WarszawaKraków: Znak, 1996.

Krzemiński I. Proces tworzenia niezależnych organizacji związkowych. Polacy-jesień'80. 1984. Z. 1.

Krzemiński I. Religia i Solidarność. Anneks. 1987. Nr. 48.

S. 21-38.

Krzemiński I. Solidarność - sens ludzkiego doświadczenia. Aneks. 1985. Nr. 40.

Krzemiński I. Religia i "Solidarność". Aneks. 1987. Nr. 48.

S. 21-38.

Kuczyński J. Wstęp do universalizmu. Vol. 1: Ogrodnicy świata. Warszawa, 1998.

Kuroń J. Myśli o programie działania. Polityka i odpowiedzialność. Anneksie. 1984. Nr. 13-14.

Kuroń J. Notatki o samorządzie. Politika i odpowiedzialność. Aneksie. 1977. Nr. 13-14.

Kuroń J. Zasady ideowe. Zł o, ktore czynię. 1984. S. 37-60. Michnik A. Dlaczego potrzebujemy Kościoła? Kościół, Lewica, dialog. Warszawa, 1998. S. 295-306.

Michnik A. Kościół, Lewica, dialog. Wybrane Adama Michnika. Zbiór pism, eseje, rozprawy i szkice z lat 1977-1997. 2017.

Michnik A. Listy z więzienia; Ugoda, praca organiczna, myśl zaprzeczna, Nowa. Warszawa, 1983.

Michnik A. Powstanie listopadowe - Polskie pytania. Krytyka. 1984. Nr. 17. S. $80-88$

Michnik A. Nowy ewolucjonizm. Szanse polskiej demokracji. Artikuł y ieseje. Aneks, 1984.

Morawska E. Civil Religion vs. State Power in Poland Society. 1984.

Ost D. Klęska "Solidarności". Gniew i politika w postcomunistycznej Europie. Warszawa, 2007

Pełczyński Z. Solidarnośc a odrodzenie społeczeństwa obywatelskiego w latach 1976-1981. Polska droga od komunizmu: refleksje nad historia i polityką 1956-2006. Warszawa, 2007.

Pełczyński Z. Wolność, państwo, społeczeństwo. Hegel a problemy współczesnej filozofii politycznej. Wrocław, 1998.

Roszkowski W. Zawieszeni w skoku. Rzeczpospolita, 2000, styczeń.

Seligman A. The Idea of Civil Society. New York: Free Press, 1992.

Smolen D. Tłum czy społecznośc zorganizowana? Strajkująncy w stoczny Gdańskiej w Sierpniu 1980. Solidarność w Ruchu 1980-1981. Warszawa, 2000.

Sollicitudo rei socialis. Encykliki Ojca Świętego Jana Pawł a II. Kraków: Znak, 1997.

Świderski B. Gdańsk i Ateny: o demokracji bezpośredniej w Polsce. Warszawa, 1996.

Świderski B. Liberalizm na niby. Przegląd Polityczny. 2004. Nr. 67/68.

Szacki J. Liberalizm po komunizmie. Demokracja. Filozofia i Praktyka. Warszawa: Znak, 1994. 263 s.

Tischner J. Etyka Solidarnosci oraz Homo Sovieticus. Warszawa: Znak, 1992. $296 \mathrm{~s}$

Walicki A. Mesjanizm Adama Mickiewicza w perspektywie porównawczej. Warszawa, 2006. $281 \mathrm{~s}$

Walicki A. Mysli o sytuacji politycznej i moralno-psychologicznej w Polsce. Aneks. 1984. Nr. 35. S. 82-104.

Wandych P. Cena wolności. Historia Europy SrodkowoWschodniej od sredniowiecza do wspólczesności. Kraków: Znak, 2006. $281 \mathrm{~s}$.

Zięba M. Papież, wolność i kapitalizm. Kraków: Znak, 1991. Внук-Липиньский Э. Социология публичной жизни; пер. с пол. Е. Генделя. Москва: Мысль, 2012. 536 с.

Шацька Б. Минуле - пам'ять - міт. Чернівці: Книги-XXI, 2011. 
Ярослав Пасько,

Київський університет ім. Бориса Грінченка (м. Київ, Україна)

e-mail: paskocivil@yahoo.com, ORCID 0000-0002-2806-7341

Геннадій Коржов,

Національний технічний університет Украӥни

"Київський політехнічний інститут ім. Ігоря Сікорського" (м. Київ, Украӥна)

e-mail: korzhovgena@yahoo.com,ORCID 0000-0001-5459-0702

\section{"СОЛІДАРНІСТЬ" ЯК СПІЛЬНОТА ГРОМАДЯНСЬКОГО СУСПІЛЬСТВА}

Запропоноване дослідження актуалізує зовнішні та внутрішні чинники, які визначають специфіку "Солідарності" як спільноти громадянського суспільства та рушійної сили соціокультурних змін в Польщі. Зовнішні фактори пов'язані з критичною інтерпретацією автономними групами польського суспільства соціального цинізму та "марксистського колективізму". Процеси соціальної корозії усвідомлюються як соціальне відчуження і логічний наслідок притаманної для радянської доби соціальної фрагментації. Фокусується увага на небезпеці втрати суспільної єдності: колізії між національною та колоніальною версіями пам'яті, соціальних викликах пов'язаних з цілісним розвитком людини та спільноти. Внутрішні чинники розглядаються в площині осмислення "Солідарності" як модернізаційної спільноти, діяльності Католицької церкви, релігійних та секулярних лідерів, в контексті еволюції незалежної профспілки від традиційної до модерної спільноти, яка базується на демократичних цінностях, соціальних та економічних мотиваціях. Теоретичний аналіз піддає осмисленню проблему громадянської довіри, культурні, релігійні та моральні чинники в діяльності "Солідарності". Проблематика останньої розглядається одночасно з республіканської та ліберальної позицій. Синтезуючи різні підходи до історичної пам'яті, досвід формування та еволюцію спільноти, окреслюється роль та значення "Солідарності" в процесі посткомуністичних ціннісних трансформацій. Запропоноване дослідження пов'язане з ціннісними передумовами формування морально-нормативної спільноти в країні колишнього соціалістичного табору, відродженням національної ідентичності, а також спробами вирішення тих історичних суперечностей, які були спровоковані комуністичним режимом. Дослідження підтверджує максиму, що реальні соціальні зміни в суспільстві є можливими лише за умови успішного поєднання в діяльності громадянського суспільства комунітарних та ліберальних складових, усування зовнішніх впливів, дистанціювання від радянської та російської історичної спадщини. Констатується, що за часів окупаційного періоду, протягом двох десятиліть в Польщі був сформований потужний інтелектуальний дискурс, який, попри несприятливий політичний контекст, став важливою консолідуючою силою польського суспільства, що успішно протистояла тоталітарним та уніфікаційним тенденціям комуністичного режиму. Інтелектуали, разом з церквою, стали рушійною силою соціальних зрушень, відіграли ключову роль в формуванні стратегії національного розвитку, змінили соціальний ландшафт комуністичної Польщі.

Ключові слова: громадянське суспільство; цінності; спільнота; солідарність; морально-нормативні засади; комунітарні та ліберальні принципи; історична пам'ять; інтелектуали; дискурс.

(C) Pasko Yaroslav, Korzhov Hennadii

Надійшла до редакції: 17.09.2019

Прийнята до друку: 04.10.2019 